\title{
ПОЛИМОРФИЗМ ЭСТЕРАЗНЫХ ИЗОФЕРМЕНТОВ В ЗРЕЛЫХ СЕМЕНАХ РЕДЬКИ ПОСЕВНОЙ (Raphanus sativus L.)
}

\author{
А.С. РУДАКОВА', С.В. РУДАКОВ', А.М. АРТЕМЬЕВА², А.Б. КУРИНА², \\ Н.В. КОЧЕРИНА ${ }^{3}$, Ю.В. ЧЕСНОКОВ ${ }^{3}$ 凶
}

Существующие внутривидовые классификации делят образцы редьки посевной (Raphanus sativus L.), проявляющие широкое разнообразие морфологических признаков, по географическому принципу в зависимости от региона происхождения (Европа, Китай, Япония). Вместе с тем известно, что в растениях комплекс ферментов, гидролизующих эфирные связи (эстеразный комплекс), имеет внутривидовую и тканевую специфичность. Ранее образцы из коллекций генетических ресурсов редьки посевной никогда не оценивались на наличие изоферментных форм эстераз в зрелых семенах этой культуры. Установление общей изменчивости изоферментных систем и выявление их генетического контроля позволяют вскрывать тонкие механизмы взаимоотношения организма с окружающей средой и гомеостаза, что особенно важно при длительном хранении образцов в генетических коллекциях семян. Существенное значение имеет и разработка эффективных биохимических маркеров для экспресс-оценки коллекционного, а также генетически и селекционно значимого материала. Проведение подобного рода работ позволяет восполнить пробел, существующий в отношении образцов генетических ресурсов редьки посевной. В настоящей работе мы впервые исследовали изоферментные формы эстераз в зрелых семенах редьки посевной и на основе полученных данных построили дендрограммы, определяющие филогенетические отношения образцов из мировой коллекции ВИР и соответствующие их ботаническому, агробиологическому и географическому положению. Была установлена средняя гетерозиготность изоферментных форм эстераз в изученных образцах и их дисперсия, указывающие на достоверность полученных результатов. Цель работы - оценить полиморфизм эстераз в зрелых семенах редьки, его зависимость от происхождения и агробиологической принадлежности образцов, а также возможность использования эстераз в качестве биохимических маркеров разнообразия вида Raphanus sativus L. Из коллекции Всероссийского института генетических ресурсов растений им. Н.И. Вавилова (ВИР) были отобраны 49 образцов редьки, принадлежащие к трем подвидам, разделенным по географическому принципу, - редька китайская, японская и европейская. Эстеразные изоферменты разделяли методом нативного электрофореза в полиакриламидном геле. Для обнаружения изоферментов гель отмывали в реактиве на неспецифическую эстеразу. Полученные зимограммы сканировали (Epson Expression 10000XL, «GE Healthcare», США). Определяли гетерозиготность популяции Нl по каждому локусу, среднюю (общую) гетерозиготность Нобщ., дисперсии гетерозиготности $\operatorname{Var}(\mathrm{Hl})$ по каждому

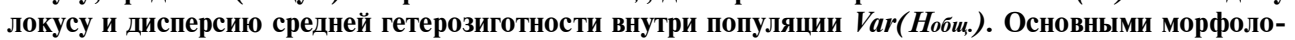
гическими и фенологическими маркерами для внутривидового деления $R$. sativus на разновидности и сортотипы были форма и окраска корнеплода и продолжительность вегетационного периода. По своему эстеразному составу все образцы подразделились на 7 зимотипов, отличающихся наличием или отсутствием тех или иных зон. Всего в эстеразном комплексе семян редьки было обнаружено 5 основных изоферментов с разной молекулярной массой, варьирующей от 45,3 кД до 35,0 кД. Все пять зон характеризовались высокой степенью полиморфизма среди представленных образцов. В зимотип № 1, представленный максимальным количеством эстераз (пять зон), входили $43 \%$ от общего числа генотипов. Зимотип № 2 составляли 33 \% образцов. Самые редкие зимотипы № 5 и № 7 (4 \%) имели минимальное количество эстеразных ферментов - по две зоны, зимотипы № 2 и № 4 - по четыре зоны, представители зимотипов № 3 и № 6 - по три зоны. Количественное соотношение эстеразных зон в образцах сильно варьировало. Минимальное содержание было выявлено для зоны В5 (4,78 \%), максимальное $(67,44 \%)$ - для зоны В1. Степень распространенности каждой зоны среди образцов составляла от 13 до $23 \%$. Самыми часто встречающимися среди всех эстеразных изоферментов были зона В3 $(\mathrm{Mr}=39,7$ кД) и В4 $(\mathrm{Mr}=37,1$ кД), они наблюдались у $23 \%$ генотипов. Для $22 \%$ представителей была характерна зона В2 (Mr= 42,9 кД). Зоны В1 $(\mathrm{Mr}=45,3$ кД) и В5 (Mr = 35 кД) встречались реже - 19 и $13 \%$. Средняя гетерозиготность изоферментных форм эстераз изученных образцов редьки составила Ноб.. $=0,212$, дисперсия для тех же образцов $\operatorname{Var}($ Нобщ.) $=0,0007$. Кластерный анализ эстеразных ферментов разделил изученный набор образцов редьки на европейские и азиатские подвиды и разновидности, а в совокупности с фенотипическими признаками позволил построить дендрограмму, соответствующую ботаническому, агробиологическому и географическому положению образцов. Следует отметить, что образцы редьки европейского подвида расположились в двух кластерах, причем образцы российского происхождения формировали отдельную группу в первом кластере, а образцы европейского происхождения входили в третий кластер, включающий также японские редьки европейского происхождения. Возможно, такое деление связано с особенностями селекции этих образцов. На основании полученных данных эстеразные ферменты рекомендуются в качестве биохимических маркеров в 
Ключевые слова: Raphanus sativus L., морфологические признаки, фенологические признаки, семена, эстеразы, изоформы, зимотипы, полиморфизм, биохимические маркеры, кластеризация.

Вид редька посевная (Raphanus sativus L.) отличается широким морфологическим разнообразием признаков листовой розетки и корнеплода. Существующие внутривидовые классификации, которыми пользуются в России (1-4), делят вид по географическому принципу в зависимости от региона происхождения (Европа, Китай, Япония). Они основаны главным образом на сильно варьирующих и зависящих от условий выращивания морфологических признаках корнеплода (окраска, форма) гетерогенных и гетерозиготных перекрестноопыляющихся образцов. В связи с этим важно найти дополнительные признаки, которые позволили бы яснее определить ход формообразовательного процесса и филогенетические связи внутри вида.

За последние два десятилетия разработаны ДНК-маркеры $(5,6)$, генетические карты (7-9) и определена последовательность всего генома японской и китайской редьки (10-12). В ряде работ отмечается эффективность и перспективность использования молекулярных маркеров RAPD (random amplified polymorphic DNA) и ISSR (inter simple sequence repeats), a также некоторых биохимических маркеров для оценки генетической изменчивости сортов редьки $(13,14)$. Такими биохимическими генетическими маркерами могут быть неспецифичные эстеразы (НЭ) - комплекс ферментов, гидролизующих эфирные связи (ЕС 3.1.1.) (15-17). Известно, что в растениях эстеразный комплекс имеет внутривидовую специфичность, кроме того, этим ферментам свойственна тканевая специфичность (18-20).

Из-за способности гидролизовать поперечные связи полисахаридов НЭ важны в создании и реорганизации клеточных стенок. Активность и изоферментный состав НЭ играют значительную роль в определенных механизмах взаимодействия растения-хозяина с патогеном (21-23), в метаболизме жирных кислот (24) и сложных эфиров холина (25). Неспецифические эстеразы также вовлечены в формирование устойчивости растений к гербицидам (26).

Показано, что активность НЭ, тесно связанная с физиологическим и метаболическим состояниями клетки, служит индикатором токсического эффекта загрязняющих веществ $(27,28)$. Факторы окружающей среды, в частности температура культивирования (29) и водный стресс (30), также влияют на активность НЭ, то есть эстеразы можно рассматривать и как потенциальные стресс-маркеры.

Коллекция Всероссийского института генетических ресурсов растений им. Н.И. Вавилова (ВИР) включает 1200 образцов редьки R. sativus из 75 стран всех континентов, в том числе 573 образца в постоянном каталоге, все подвиды, разновидности и сортотипы культуры.

Мы впервые исследовали изоферментные формы эстераз в зрелых семенах редьки посевной и на основе полученных данных построили дендрограммы, определяющие филогенетические отношения образцов из мировой коллекции ВИР и соответствующие их ботаническому, агробиологическому и географическому положению. Была установлена средняя гетерозиготность изоферментных форм эстераз в изученных образцах и их дисперсия, указывающие на достоверность полученных результатов.

Цель работы - оценить полиморфизм эстераз в зрелых семенах редьки, его зависимость от происхождения и агробиологической принадлежности образцов, а также возможность использования эстераз в качестве 
биохимических маркеров разнообразия вида Raphanus sativus L.

Mетодика. Зрелые семена восьми разновидностей вида Raphanus sativus L. (всего 49 генотипов) различного происхождения (коллекция ВИР) растирали в фарфоровой ступке до состояния муки. В пробирки типа эппендорф вносили по 100 мг полученной муки и приливали по 2 мл предварительно охлажденного гексана. Образцы периодически встряхивали и оставили на ночь в холодильнике при 4-8 ${ }^{\circ} \mathrm{C}$. На следующий день пробирки центрифугировали (Eppendorf centrifuge 5410, «Eppendorf AG», Германия) 10 мин при 15000 об/мин, надосадочную жидкость удаляли, а осадок обезжиренной муки оставляли под тягой для высушивания на воздухе. Эстеразные ферменты из обезжиренного и высушенного растительного материала экстрагировали $0,05 \mathrm{M}$ Трис- $\mathrm{HCl}$ буфером (соотношение мука:буфер - 1:4) при рН 8,3 и 4-8 ${ }^{\circ} \mathrm{C}$ на протяжении 14-18 ч. После центрифугирования при 15000 об/мин в течение 10 мин ферментные вытяжки сливали с осадка и замораживали при $-20{ }^{\circ} \mathrm{C}$. Образцы размораживали перед проведением электрофореза и вносили в карманы концентрирующего геля.

Эстеразные изоферменты разделяли методом нативного электрофореза в полиакриламидном геле (31) с концентрациями разделяющего и концентрирующего геля соответственно 11 и 5 \%. Для электрофореза использовали камеру Mini-PROTEAN Tetra Cell («Bio-Rad Laboratories, Inc.», США). Концентрацию белков в ферментных вытяжках оценивали методом M.M. Bradford (32). Для определения молекулярных масс исследуемых ферментов в последний карман геля вносили маркер Prestained Protein Ladder («Thermo Scientific», США). Все образцы вносились в карманы геля по 1520 мкл в зависимости от концентрации белка в ферментной вытяжке. Электрофорез проводили при 6-10 ${ }^{\circ} \mathrm{C}$ и 10 В/см в течение 2,5 ч. Для обнаружения изоферментов гель отмывали в реактиве на неспецифическую эстеразу (33) в течение 10-15 мин до проявления зон. Для этого гель флотировали в свежем растворе красителя и субстратов, состоящем из 100 мг $\alpha$-нафтилацетата и 120 мг $\beta$-нафтилацетата («Sigma-Aldrich Chemie GmbH», Швейцария), растворенных в 10 мл $70 \%$ этанола, 500 мг Fast Blue RR («SigmaAldrich Co.», США), 4 мл пропанола и 60 мл 0,1 М фосфатного буфера (pH 6,0). Остатки красителя удаляли 7 \% уксусной кислотой.

Полученные зимограммы сканировали (Epson Expression 10000XL, «GE Healthcare», США). Расчет количественного соотношения всех зон, обнаруженных в треке, и определение молекулярных масс по соответствующим стандартам на основе показателя Rf рассчитывали в программе Phoretix 1D Advansed («TotalLab, Ltd.», Великобритания).

Гетерозиготность популяции $H_{l}$ по каждому локусу, а также среднюю (общую) гетерозиготность Нобщ. вычисляли по формулам $(34,35)$ :

$$
\begin{gathered}
H_{l}=2 n\left(1-\sum_{k} x_{k}^{2}\right) / 2 n-1, \\
H_{\text {общ. }}=\sum_{l=1}^{r} H_{l} / r,
\end{gathered}
$$

где $l-$ порядковый номер локуса, $n-$ размер популяции, $x_{k}-$ частота $k$ го аллеля $l$-го локуса, $r$ - общее число локусов.

Рассчитывали дисперсии гетерозиготности $\operatorname{Var}(H l)$ по каждому локусу и дисперсию средней гетерозиготности внутри популяции $\operatorname{Var}\left(H_{о б щ .)}\right.$ (36):

$$
\begin{gathered}
\operatorname{Var}\left(H_{l}\right)=H_{l}\left(1-H_{l}\right) / n, \\
\operatorname{Var}\left(H_{\text {общ. }}\right)=\frac{1}{n r^{2}} \sum_{l} H_{l}\left(1-H_{l}\right)+\frac{1}{n r^{2}} \sum_{l} \sum_{l \neq \hat{\imath}}\left(H_{l \hat{l}}-H_{l} H_{\hat{l}}\right) .
\end{gathered}
$$

Морфологическое и агробиологическое описание образцов проводили по Л.В. Сазоновой с соавт. (37) (научно-производственная база «Пушкинские и Павловские лаборатории ВИР», г. Санкт-Петербург). 
Основными морфологическими и фенологическими маркерами для внутривидового деления $R$. sativus на разновидности и сортотипы были форма и окраска корнеплода и продолжительность вегетационного периода $(1,37)$. При построении матрицы для кластерного анализа использовали следующие количественные и качественные признаки: длина и диаметр корнеплода, индекс корнеплода (отношение длины к диаметру), окраска поверхности коры корнеплода (1 - белая, 3 - зеленая, 5 - розовая, 7 красная, 9 - черная), форма корнеплода (2 - коническая, 3 - цилиндрическая, 4 - эллиптическая, 5 - округлая, 6 - плоскоокруглая, 7 - цилиндрическая со сбегом вверх), тип листа (1 - цельный, 3 - лировидный), опушенность листовой пластинки (0 - без опушения, 1 - опушенный $)$, продолжительность вегетационного периода. Качественные признаки оценивали в баллах согласно дескриптору (38).

Кластерный анализ образцов по результатам анализа только эстеразных ферментов и комплекса признаков (морфологических, фенологических и эстеразного состава семян) выполняли методом UPGMA с использованием программы PAST (http://sonraid.ru/past/), включая bootstrap-анализ.

Результаты. Список образцов редьки, изученных в работе, представлен в таблице 1.

1. Список образцов редьки посевной Raphanus sativus L. (коллекция Всероссийского института генетических ресурсов растений им. Н.И. Вавилова ВИР), у которых был изучен полиморфизм эстераз в зрелых семенах

\begin{tabular}{|c|c|c|c|c|c|}
\hline $\begin{array}{l}\text { Номер в } \\
\text { каталоге } \\
\text { ВИР } \\
\end{array}$ & Название образца & $\begin{array}{l}\text { Происхожде- } \\
\text { ние }\end{array}$ & $\begin{array}{l}\text { Группа разновидностей } \\
\text { (convar.) }\end{array}$ & Разновидность (var.) & $\begin{array}{l}\text { Номер } \\
\text { на зимо- } \\
\text { грамме }\end{array}$ \\
\hline \multicolumn{6}{|c|}{ Р е д ь к а е в р о п ей с к а я $R$. sativus subsp. sativus (L.) Sazon. } \\
\hline K-1675 & Белая Аджарская & Грузия & sativus Sazon. & sativus Sazon. & 3 \\
\hline K-1833 & Одесская 5 & Белоруссия & sativus Sazon. & sativus Sazon. & 7 \\
\hline K-2163 & Майская белая & Россия & sativus Sazon. & sativus Sazon. & 44 \\
\hline K-1778 & \multicolumn{5}{|l|}{ Зимняя круглая чер- } \\
\hline & ная & Германия & hybernus (Alef.) Sazon. & niger (L.) Sinsk. & 4 \\
\hline K-1892 & Dazwish ali & Египет & hybernus (Alef.) Sazon. & niger (L.) Sinsk. & 9 \\
\hline K-1971 & Round Black Spanish & США & hybernus (Alef.) Sazon. & niger (L.) Sinsk. & 15 \\
\hline K-1764 & Местная & Россия & hybernus (Alef.) Sazon. & niger (L.) Sinsk. & 26 \\
\hline$K-2115$ & Черная & Россия & hybernus (Alef.) Sazon. & niger (L.) Sinsk. & 35 \\
\hline K-2124 & & Турция & hybernus (Alef.) Sazon. & niger (L.) Sinsk. & 36 \\
\hline K-1914 & Зимняя круглая бе- & & & & \\
\hline & лая & Россия & hybernus (Alef.) Sazon. & hybernus (Alef.) Sazon. & 28 \\
\hline K-2025 & Сквировская белая & Украина & hybernus (Alef.) Sazon. & hybernus (Alef.) Sazon. & 32 \\
\hline \multicolumn{6}{|c|}{ Р ед ь к а к } \\
\hline K-698 & & Малая Азия & lobo Sazon. et Stankev. & lobo Sazon. et Stankev. & 1 \\
\hline K-1805 & & Средняя Азия & lobo Sazon. et Stankev. & lobo Sazon. et Stankev. & 5 \\
\hline K-1902 & Белая зеленоголовая & Китай & lobo Sazon. et Stankev. & lobo Sazon. et Stankev. & 11 \\
\hline K-1978 & Местная & Киргизия & lobo Sazon. et Stankev. & lobo Sazon. et Stankev. & 16 \\
\hline$K-2101$ & Chinese White Winter & Чили & lobo Sazon. et Stankev. & lobo Sazon. et Stankev. & 21 \\
\hline K-2074 & Местная & Египет & lobo Sazon. et Stankev. & lobo Sazon. et Stankev. & 33 \\
\hline $\mathrm{K}-2151$ & Altari mu & Южная Корея & lobo Sazon. et Stankev. & lobo Sazon. et Stankev. & 39 \\
\hline K-1815 & Маргиланская & Узбекистан & lobo Sazon. et Stankev. & virens Sazon. & 6 \\
\hline K-1865 & Вэй-сян & Китай & lobo Sazon. et Stankev. & virens Sazon. & 8 \\
\hline$K-2000$ & Местная & Узбекистан & lobo Sazon. et Stankev. & virens Sazon. & 17 \\
\hline K-2148 & Местная & Казахстан & lobo Sazon. et Stankev. & virens Sazon. & 38 \\
\hline $\mathrm{K}-725$ & & Малая Азия & lobo Sazon. et Stankev. & rubidus Sazon. & 2 \\
\hline K-1895 & Хун-дын-лун & Китай & lobo Sazon. et Stankev. & rubidus Sazon. & 10 \\
\hline K-1903 & Красная & Китай & lobo Sazon. et Stankev. & rubidus Sazon. & 12 \\
\hline K-1935 & Nerima Pointed rooted & Япония & lobo Sazon. et Stankev. & rubidus Sazon. & 13 \\
\hline K-1857 & Чан-шун-лобо & Китай & lobo Sazon. et Stankev. & rubidus Sazon. & 27 \\
\hline K-1967 & Местная & Афганистан & lobo Sazon. et Stankev. & rubidus Sazon. & 30 \\
\hline K-1983 & Нежная & Россия & lobo Sazon. et Stankev. & rubidus Sazon. & 31 \\
\hline & Р е д ь к а & Я П о н с к а Я & sativus subsp. acanthiformis & (Blanch) Stankev. & \\
\hline K-1958 & Hakata haruwaka & Япония & minowase (Kitam.) Sazon. & minowase Kitam. & 14 \\
\hline K-2033 & Turnip & Япония & minowase (Kitam.) Sazon. & minowase Kitam. & 18 \\
\hline K-2063 & Unzen shigatsu & Япония & minowase (Kitam.) Sazon. & minowase Kitam. & 20 \\
\hline K-2111 & Минотоки №2 & Япония & minowase (Kitam.) Sazon. & minowase Kitam. & 22 \\
\hline K-1946 & Unsen-4-gatsu & Япония & minowase (Kitam.) Sazon. & minowase Kitam. & 29 \\
\hline K-2134 & Eifuku 2 & Япония & minowase (Kitam.) Sazon. & Minowase Kitam. & 37 \\
\hline
\end{tabular}


Нидерланды Япония Япония Япония Южная Корея Франция Япония Япония Япония Eifuku

Shinuchi Sobutori F1 Япония Back-ok

Mijshige long pointed rooted Япония Япония

Южная Корея Южная Корея minowase (Kitam.) Sazon. minowase (Kitam.) Sazon. minowase (Kitam.) Sazon. minowase (Kitam.) Sazon. minowase (Kitam.) Sazon. minowase (Kitam.) Sazon. minowase (Kitam.) Sazon. acanthiformis (Blanch) Stankev. acanthiformis (Blanch) Stankev. acanthiformis (Blanch) Stankev. acanthiformis (Blanch) Stankev.

acanthiformis (Blanch) Stankev. acanthiformis (Blanch) Stankev. acanthiformis (Blanch) Stankev.
Продолжение таблицы 1

minowase Kitam. minowase Kitam. minowase Kitam. minowase Kitam. minowase Kitam. minowase Kitam. minowase Kitam.

$\begin{array}{ll}\text { Kitam. } & 49 \\ - & 19 \\ - & 23 \\ - & 24 \\ - & 25 \\ - & \\ - & 34 \\ - & 45 \\ - & 46\end{array}$

П р и м е ч а н и е. Прочерки означают, что разновидности не выделены.

При помощи нативного электрофореза в семенах 49 генотипов редьки были выявлены пять основных изоферментов эстераз: В1 (молекулярная масса 45,3 кД), В2 (42,9 кД), В3 (39,7 кД), В4 (37,1 кД), В5 (35,0 кД) (рис. 1). Все пять зон характеризовались полиморфизмом среди представленных образцов (табл. 2). Мономорфных зон (то есть присутствующих во всех образцах) мы не обнаружили.

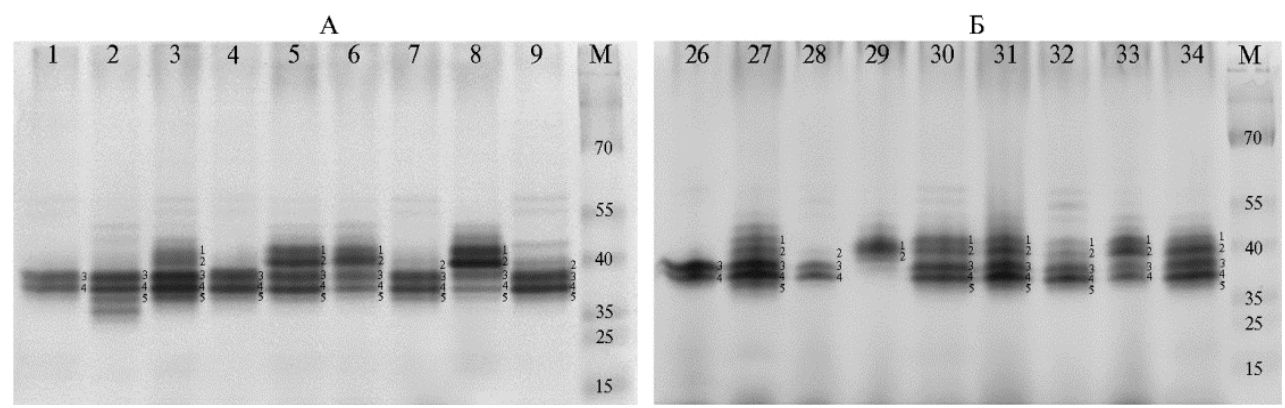

Рис. 1. Зимограммы эстеразных ферментов в зрелых семенах редьки посевной Raphanus sativus $\mathbf{L}$. (коллекция Всероссийского института генетических ресурсов растений им. Н.И. Вавилова ВИР). Вдоль дорожек справа обозначены зоны эстераз, над дорожками указаны номера образцов в соответствии с таблицей 1. М - маркеры молекулярных масс (15-70 кД; Prestained Protein Ladder, «Thermo Scientific», США).

2. Эстеразный состав зимотипов в зрелых семенах редьки посевной Rahanus sativus L. (коллекция Всероссийского института генетических ресурсов растений им. Н.И. Вавилова - ВИР)

\begin{tabular}{|c|c|c|c|c|c|c|}
\hline Зимотип & $\begin{array}{c}\text { B1 } \\
(45,3 \mathrm{~K} \Omega)\end{array}$ & $\begin{array}{c}\text { В2 } \\
(42,9 \text { КЛ })\end{array}$ & $\begin{array}{c}\text { B3 } \\
(39,7 \text { кЛ })\end{array}$ & $\begin{array}{c}\text { В4 } \\
(37,1 \mathrm{~K} \Omega)\end{array}$ & $\begin{array}{c}\text { В5 } \\
(35,0 \text { кЛ })\end{array}$ & $\begin{array}{l}\text { Общее } \\
\text { число зон }\end{array}$ \\
\hline № 1 & + & + & + & + & + & 5 \\
\hline № 2 & + & + & + & + & - & 4 \\
\hline № 3 & - & + & + & + & - & 3 \\
\hline № 4 & - & + & + & + & + & 4 \\
\hline № 5 & - & - & + & + & - & 2 \\
\hline № 6 & - & - & + & + & + & 3 \\
\hline № 7 & + & + & - & - & - & 2 \\
\hline Всего & 38 & 45 & 48 & 48 & 26 & 205 \\
\hline Частота зоны, \% & 19 & 22 & 23 & 23 & 13 & 100 \\
\hline
\end{tabular}

По эстеразному составу все образцы были разделены на семь зимотипов, отличающихся друг от друга наличием или отсутствием тех или иных зон (табл. 2, 3).

Количественное соотношение эстеразных зон в исследованных образцах сильно варьировало (табл. 4). Распространенность каждой зоны составляла от 13 до 23 \%. Минимальное содержание было выявлено для зоны 
В5 (4,78 \%), максимальное - для В1 $(67,44$ \%). Среднестатистическое значение содержания эстеразных изоферментов варьировало от 11,48 (для зоны В5) до 29,28\% (для зоны В3).

3. Распределение образцов зрелых семян редьки посевной Rahanus sativus L. (коллекция Всероссийского института генетических ресурсов растений им. Н.И. Вавилова - ВИР) по эстеразным зимотипам

\begin{tabular}{|c|c|c|c|c|}
\hline Зимотип & $\begin{array}{l}\text { Число зон } \\
\text { в зимотипе }\end{array}$ & Номера образцов на зимограмме & \begin{tabular}{|l|} 
Всего \\
генотипов
\end{tabular} & $\begin{array}{l}\text { Доля от общего } \\
\text { числа генотипов, \% }\end{array}$ \\
\hline № 1 (B1-B5) & 5 & $\begin{array}{l}3,5,6,8,10-14,16,17,23,24,27,30-32 \\
34,38,40,48\end{array}$ & 21 & 43 \\
\hline № 2 (B1-B4) & 4 & $18-22,25,33,36,37,39,41,42,44-46,49$ & 16 & 33 \\
\hline № 3 (B2-B4) & 3 & $28,35,43,47$ & 4 & 8 \\
\hline № 4 (B2-B5) & 4 & $7,9,15$ & 3 & 6 \\
\hline № 5 (B3-B4) & 2 & 1,26 & 2 & 4 \\
\hline № 6 (B3-B5) & 3 & 2,4 & 2 & 4 \\
\hline № 7 (B1-B2) & 2 & 29 & 1 & 2 \\
\hline
\end{tabular}

4. Количественное содержание эстеразных изоферментов в зрелых семенах редьки посевной Rahanus sativus L. (коллекция Всероссийского института генетических ресурсов растений им. Н.И. Вавилова - ВИР)

\begin{tabular}{l|c|c|r|r|r}
\hline \multicolumn{1}{c|}{ Показатель } & B1 & B2 & B3 & B4 & B5 \\
\hline Мr, кД & 45,3 & 42,9 & 39,7 & 37,1 & 35,0 \\
Min, \% & 7,06 & 7,78 & 16,77 & 8,74 & 2,78 \\
Мах, \% & 67,44 & 39,91 & 54,22 & 52,10 & 25,96 \\
Среднее, \% & 20,11 & 25,16 & 29,28 & 26,60 & 11,48
\end{tabular}

П р и м е ч н и е. $\mathrm{M}_{\mathrm{r}}$ - молекулярная масса, Min - минимальное количество, Мах - максимальное количество.

К зимотипу № 1 (5 зон эстераз) относились $43 \%$ от общего количества генотипов. Основная часть этой группы была представлена образцами китайского подвида зеленой (var. virens Sazon.), розово-красной (var. rubidus Sazon.) и белой (var. lobo) разновидностей из Китая и Средней Азии. Кроме того, в эту группу входили шесть образцов японской редьки европейского и японского происхождения и образец летней европейской редьки. Зимотип № 2 (4 зоны) был характерен для $33 \%$ изученных образцов. В эту группу вошли в основном образцы редьки японского подвида из Японии и Южной Кореи, несколько генотипов лобы белой разновидности из Египта и Чили и два образца европейской летней и зимней редьки. Зимотип № 3 (3 зоны) был представлен двумя образцами зимней европейской редьки из России и двумя образцами дайкона осеннего типа и составил $8 \%$ от всех генотипов. Зимотип № 4 (4 зоны) составили три образца (6 \%) европейской редьки, в то время как зимотипы № 5 (2 зоны) и № 6 (3 зоны) включали по два образца (4 \%) - местные лобы малоазиатского происхождения и зимние черные редьки. Наименее распространенным, то есть имеющим самый редкий состав эстераз, оказался один образец дайкона Unzen-4-gatsu (к-1946, Япония), принадлежащий к зимотипу № 7 (2 зоны). Частота встречаемости такого зимотипа составила $2 \%$.

Определение частоты гетерозигот - один из важнейших этапов исследования популяции, поскольку каждая гетерозигота несет разные аллели и иллюстрирует наличие изменчивости. Следует отметить, что чем меньше разница между величинами частот аллелей локуса, тем выше получаемое значение гетерозиготности по этому локусу. По результатам проведенного нами подсчета самое большое значение гетерозиготности $H_{l}=0,503$ было установлено у изоформы В5 (табл. 5). У изоформ В3 и В4 было выявлено всего по одному полиморфному аллелю и, соответственно, значения гетерозиготности оказались самыми низкими (по $\left.H_{l}=0,039\right)$. Дисперсия - это зависимая 
от гетерозиготности величина, и потому выявленные для гетерозиготности закономерности аналогичны таковым для дисперсии. Применение формулы расчета дисперсии средней гетерозиготности (36) обусловлено ковариациями между гетерозиготностями по локусам $l$ и $\hat{l}$, определяемыми частотами двойных гетерозигот $H_{l \hat{l}}$ по этим локусам.

5. Результаты расчета гетерозиготности популяции и дисперсии гетерозиготности у образцов редьки посевной Rahanus sativus L. (коллекция Всероссийского института генетических ресурсов растений им. Н.И. Вавилова - ВИР) по результатам изоферментного анализа

\begin{tabular}{l|c|c|c|c|c}
\hline \multicolumn{1}{c|}{ Статистический } & \multicolumn{5}{|c}{ Изоферментные локусы (зоны эстераз) } \\
\cline { 2 - 6 } показатель & $\mathrm{B} 1$ & $\mathrm{~B} 2$ & $\mathrm{~B} 3$ & $\mathrm{~B} 4$ & $\mathrm{~B} 5$ \\
\hline Гетерозиготность $\mathrm{Hl}$ & 0,328 & 0,152 & 0,039 & 0,039 & 0,503 \\
Дисперсия $\operatorname{Var}\left(\mathrm{H}_{l}\right)$ & 0,004 & 0,002 & 0,001 & 0,001 & 0,005
\end{tabular}

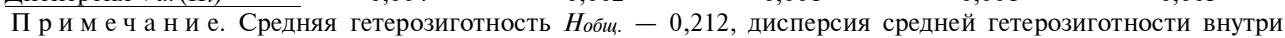

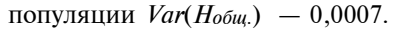

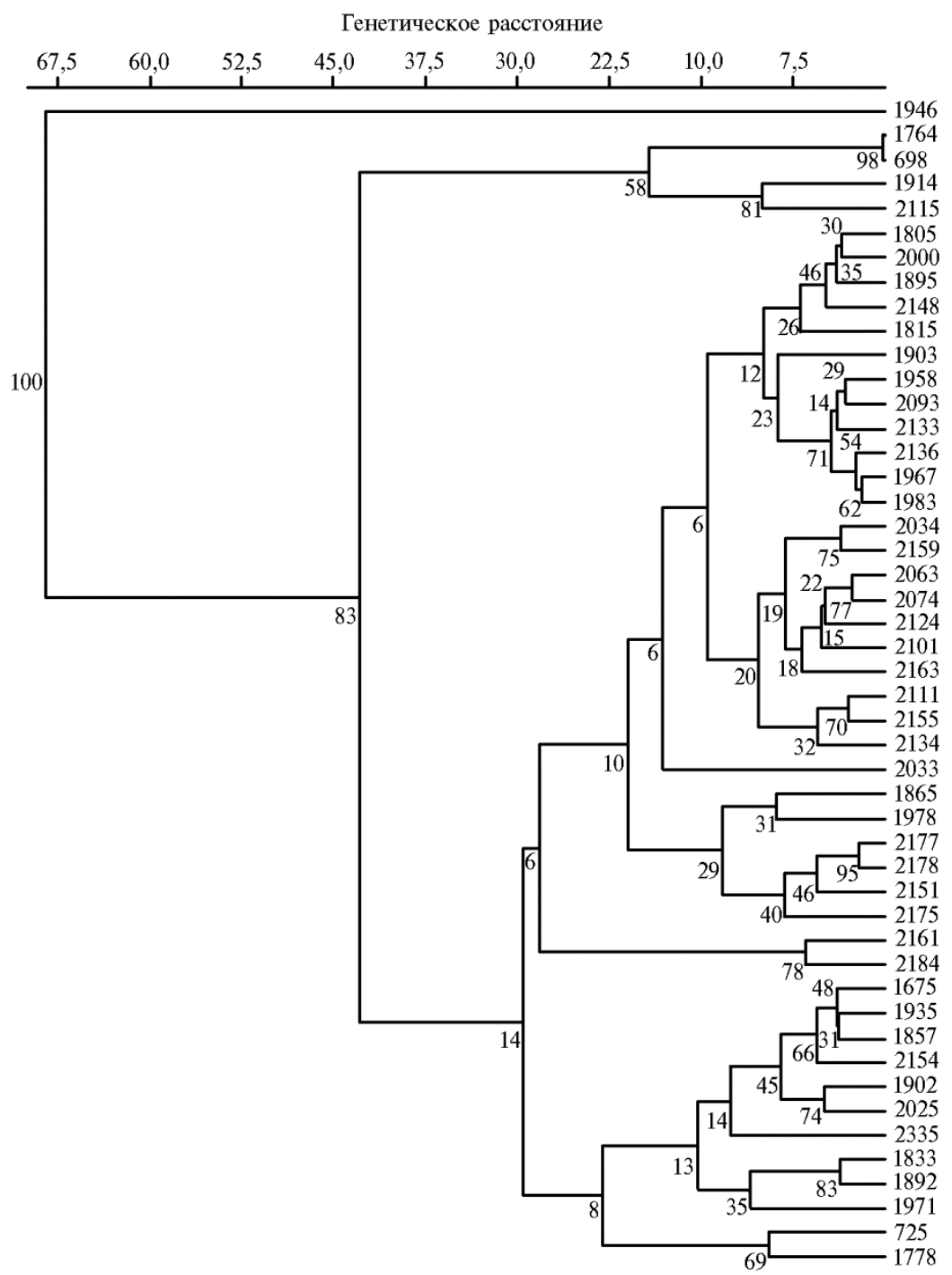

Рис. 2. UPGMA-дендрограмма, характеризующая степень генетического сходства образцов редьки посевной Rahanus sativus L. (коллекция Всероссийского института генетических ресурсов растений им. Н.И. Вавилова - ВИР) по эстеразному составу семян. Значения bootstrap-анализа на ветвях древа указывают расстояния связывания. Описание генотипов (номера справа) представлено в таблице 1 . 
Необходимо отметить, что использованные в нашей работе формулы дают возможность решить любой многочлен в наборе переменных, распределенных мультиноминально, и рассчитываемая гетерозиготность расценивается как мера информационного полиморфизма, активно применяемая при составлении и реализации генетико-селекционных программ.

В целом по результатам изоферментного анализа было найдено 205 электрофоретических полос изоформ эстераз, которые использовали для построения дендрограммы (рис. 2). Образцы редьки оказались сгруппированы в один большой и два малых кластера. При этом образец дайкона Unzen-4-gatsu (к-1946, Япония) занял позицию out-group. Первый малый кластер включал образцы европейских зимних редек из России (var. niger (L.) Sinsk.; var. hybernus) и местный образец белой лобы из Малой Азии (к-698). Второй большой кластер в основном включал образцы редьки китайского и японского подвида и был разделен на четыре подкластера. Первый подкластер образовывали образцы лобы из России, Афганистана, Китая (var. rubidus Sazon.), Узбекистана и Казахстана (var. virens Sazon.), а также дайконы весеннего и осеннего сортотипов. Второй подкластер включал образцы японских и европейских редек (var. sativus; var. niger (L.) Sinsk.), лобы из Египта и Чили (var. lobo). За пределами первых двух подкластеров оказался расположен образец дайкона к-2033. В третий подкластер входили образцы лобы из Южной Кореи, Киргизии, Китая (var. lobo; var. virens Sazon.) и дайконы из Южной Кореи и Японии, при этом генотипы из Южной Кореи и Японии образовывали две отдельных группы внутри подкластера. Четвертый подкластер включал два образца дайкона из Южной Кореи и Японии.

В третьем кластере на дендрограмме были расположены преимущественно образцы редьки европейского подвида, а также японского подвида, но европейского происхождения. Кластер разделился на два подкластера: в первом находились европейские зимние редьки из Канады и Египта (var. niger (L.) Sinsk.) и летняя редька из Белоруссии (var. sativus), во втором - дайконы из Франции и Нидерландов, белые европейские редьки из Украины и Грузии (var. hybernus; var. sativus) и китайские редьки из Китая и Японии (var. rubidus Sazon.; var. lobo). За пределами подкластеров остались два образца: зимняя черная редька из Германии и лоба из Малой Азии.

По фенотипическим признакам изученные образцы редьки сгруппировались в пять кластеров (полученная нами дендрограмма не показана, поскольку она соответствовала их ботаническому и агробиологическому делению). В отдельные кластеры вошли образцы зимних и летних европейских редек. Азиатские редьки были представлены двумя кластерами (образцами японского и китайского подвида), причем не отмечалось существенных различий между образцами разного эколого-географического происхождения. Последний кластер объединял несколько образцов лобы из Средней и Малой Азии и Чили и образец дайкона местной сортопопуляции из Японии. То есть филогенетическая картина, полученная при использовании только фенотипических признаков, не совсем полно отражала особенности формообразования изученных образцов редьки.

На дендрограмме, построенной на основе результатов комплексного анализа морфологических и фенологических признаков, включая эстеразный состав семян (рис. 3), присутствовали большой и два малых кластера. За их пределами, как и на рисунке 2, находился японский образец дайкона Unzen4-gatsu (к-1946). В первом кластере группировались образцы редек европейского подвида, разделенного на два подкластера. Первый включал образцы 
зимней редьки черной (var. niger (L.) Sinsk.) и белой (var. hybernus) разновидности, второй - генотипы редьки китайской малоазиатского происхождения (к-725, к-698), которые были местными сортопопуляциями.

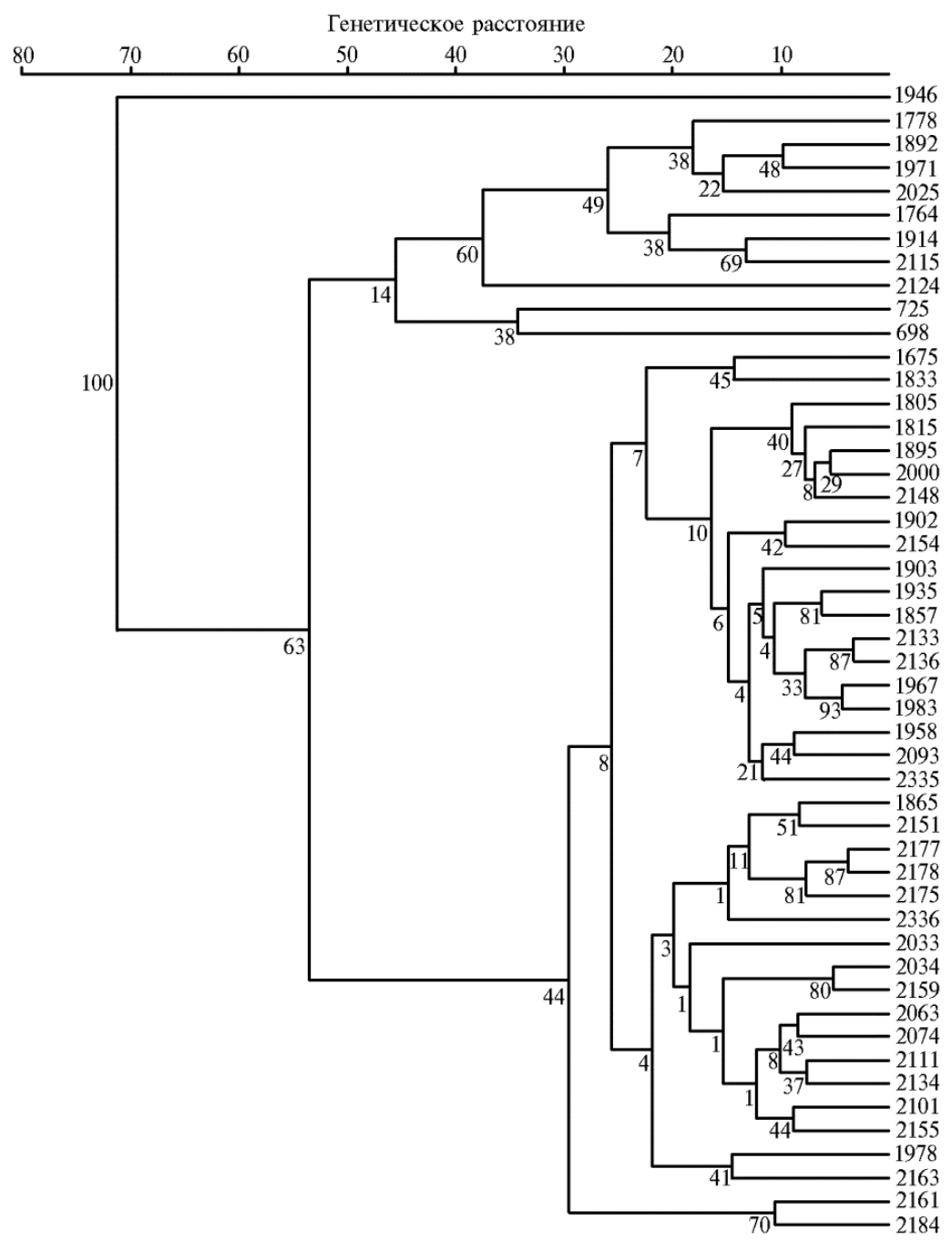

Рис. 3. UPGMA-дендрограмма, характеризующая степень генетического сходства образцов редьки посевной Rahanus sativus L. (коллекция Всероссийского института генетических ресурсов растений им. Н.И. Вавилова - ВИР) по комплексу морфологических и фенологических признаков, включая эстеразный состав семян. Значения bootstrap-анализа на ветвях древа указывают расстояния связывания. Описание генотипов (номера справа) представлено в таблице 1.

Во втором большом кластере располагались образцы китайского и японского подвида, а также летней европейской редьки. Кластер был разделен на четыре подкластера. Первый включал два образца летней европейской редьки (var. sativus) из Белоруссии и Грузии. Во второй входили отдельная группа образцов лобы среднеазиатского происхождения, группа образцов лобы розово-красной разновидности (var. rubidus Sazon.) из Китая, России, Афганистана и дайконы из Японии, Франции и Нидерландов. В третьем подкластере были расположены две большие группы образцов: первая включала генотипы лобы и дайкона из Южной Кореи с примыкающим образцом дайкона из Японии (к-2336), вторая - образцы дайкона из Японии и два образца лобы белой разновидности из Египта (к-2074) и Чили (к-2101). Четвертый подкластер включал лишь два образца: лоба белой разновид- 
ности из Киргизии (Местная, к-1978) и летняя европейская редька из России (Майская, к-2163). В третьем малом кластере находились два образца дайкона из Японии и Южной Кореи.

Сравнительное изучение образцов редьки по изоферментному составу эстераз позволило выявить внутривидовой полиморфизм и разделить их на семь зимотипов с разным количественным соотношением эстеразных зон. Наличие всех пяти эстеразных зон (зимотип № 1) было характерно в большей степени для образцов китайского подвида, что указывает на большие межсортовые различия внутри подвида. Наличие четырех эстеразных зон (зимотипы № 2 и № 4) наблюдалось в основном у образцов японского и европейского подвида. Три (группы № 3 и № 6) и две (группы № 5 и № 7) эстеразные зоны обнаруживали у образцов европейской зимней редьки из России, дайкона из Японии и Южной Кореи и лобы из Малой Азии. Образцы, принадлежащие к зимотипам № 3 и № 6, были селекционными сортами, созданными предположительно в результате индивидуального отбора из сортопопуляций или посредством гибридизации с последующим отбором. К зимотипам № 5 и № 7 относились образцы местного происхождения, несмотря на это им присуща высокая внутрисортовая однородность, возможно, их селекция происходила локализовано в определенной местности.

Следовательно, наличие у этих образцов редко встречающихся эстеразных зон связано с особенностями их селекции или агробиологической принадлежностью, что согласуется с результатами других работ $(15-17,39)$. Так, нами (15-17) впервые была показана возможность использования оценки полиморфизма изоферментных форм эстераз для установления генетического полиморфизма не только у редиса (Raphanus sativus L.) и линий удвоенных гаплоидов Brassica rapa L., но и у гексаплоидной яровой пшеницы (Triticum aestivum L.). Схожие результаты были получены и при изучении полиморфизма различных сортов пшеницы (Triticum L.) (39). Bo всех указанных работах выявлен полиморфизм изоферментного профиля эстераз, выделенных из зрелых семян, у образцов сортового, линейного и коллекционного селекционного материала. Показано широкое разнообразие электрофоретических профилей эстеразных изоферментов зрелых семян и установлена возможность определения полиморфизма эстераз в гибридных поколениях. Наряду с полученными нами в настоящем исследовании результатами это позволяет не только выделить перспективный исходный материал для селекции, но и рекомендовать такой тип биохимических маркеров для решения практических задач в качестве средства, способного ускорить и упростить процесс отбора селекционно значимого материала. Тот факт, что аналогичных работ на редисе, редьке посевной, $B$. rapa, пшенице ранее не проводили, еще раз подчеркивает перспективность использования предложенного нами подхода.

Кластерный анализ эстеразного состава семян показал, что образцы группировались в основном по происхождению и частично в связи с ботанической принадлежностью. Образцы редьки европейского подвида располагались в двух кластерах, причем образцы российского происхождения формировали отдельную группу в первом кластере, а образцы европейского происхождения входили в третий кластер, включающий также японские редьки европейского происхождения. Возможно, такое деление связано с особенностями селекции этих образцов.

Во второй большой кластер азиатских редек попали не только образцы китайского и японского подвида, но и несколько образцов европейского подвида летней и зимней групп разновидностей, что могло быть 
связано с особенностями формообразования этих образцов или с ошибкой при репродуцировании. Интересно, что южнокорейские образцы, независимо от их ботанической принадлежности, сформировали отдельную группу внутри третьего подкластера, что внесло важное дополнение во внутривидовую дифференциацию.

Таким образом, в отдельные кластеры оказались распределены европейские и азиатские образцы, что подтверждает происхождение разнообразия редек из двух первичных географических центров - Средиземноморского и Азиатского $(2,4)$.

Кластеризация образцов по комплексу признаков (морфологические, фенологические и эстеразный состав семян) показала результаты, наиболее согласующиеся с ботаническим и агробиологическим делением. Первый кластер включал все образцы зимних европейских редек и две сортопопуляции лобы. Второй большой кластер объединял образцы китайского и японского подвида, а также летней европейской редьки. Летние европейские редьки считаются промежуточными формами между европейской зимней редькой и редисом, а лобы - исходными формами японских редек и китайских редисов. Возможно, эта особенность и объединяет эти две группы разновидностей в один кластер. В третьем кластере была расположена группа образцов лобы и дайкона из Южной Кореи, как и на первой дендрограмме. Это уточнение выявлено благодаря анализу эстеразных ферментов и, вероятно, указывает на множественное происхождение японских редек (3).

Образец дайкона Unzen-4-gatsu (к-1946, Япония) выделился редким наличием эстеразных зон (зимотип № 7) и занял позицию out-group. Он принадлежал к морфологически резко отличному от остальных сортотипу Ниненго, характерной особенностью которого было наличие длинного тонкого корнеплода (длина 50-55 см, диаметр 5-6 см) и крупной розетки листьев (высота 25-30 см, диаметр 35-40 см). Сорта этой группы наиболее устойчивы к заморозкам и стеблеванию (40).

Итак, проведенный биохимический анализ эстераз зрелых семян образцов редьки разного происхождения выявил наличие полиморфизма изоформ этого фермента. Расчет гетерозиготности в каждом локусе $H_{l}$ и общей гетерозиготности популяции Нобщ. позволил установить наиболее (B5) и наименее (B3 и В4) гетерозиготные изоформы эстераз. Использованные в настоящей работе формулы дают возможность решить любой многочлен в наборе переменных, распределенных мультиноминально. При составлении и реализации генетико-селекционных программ рассчитанная гетерозиготность Нобщ. $=0,212$ и дисперсия для тех же образцов $\operatorname{Var}(\text { Нобщ. })_{=0,0007}$ могут расцениваться как эффективная мера информационного полиморфизма. Кроме того, проведенный кластерный анализ по эстеразному составу семян, а также фенотипическим признакам показал результаты, наиболее согласующиеся с ботаническим и агробиологическим делением разнообразия редек по происхождению из двух первичных географических центров. Следовательно, эстеразы зрелых семян редьки посевной - удобные биохимические маркеры, которые могут быть использованы при проведении как физиолого-биохимических, так и генетико-селекционных исследований образцов этой культуры.

\section{Л ИТ ЕРАТ У РА}

1. Синская Е.Н. Редис и редька (Raphanus sativus L.). Труды по прикладной ботанике, генетике и селекции, 1928, 19(3): 448-534. 
2. Синская Е.Н. К генезису культурных форм рода Raphanus L. Tруды по прикладной ботанике, генетике и селекции, 1931, 26(2): 3-58.

3. Сазонова Л.В. Внутривидовая классификация корнеплодных форм Raphanus sativus L. Труды по прикладной ботанике, генетике и селекции, 1971, 45(1): 42-75.

4. Шебалина М.А., Сазонова Л. В. Культурная Флора СССР. Т. 18. Корнеплодные растения (семейство Капустные - репа, турнепс, брюква, редька, редис) /Под ред. В.Т. Красочкина, В.И. Буренина. Л., 1985.

5. Tsuro M., Suwabe K., Kubo N., Matsumoto S., Hirai M. Mapping of QTLs controlling root shape and red pigmentation in radish, Raphanus sativus L. Breeding Science, 2008, 58(1): 55-61 (doi: $10.1270 /$ jsbbs.58.55).

6. Mun J.H., Chung H., Chung W.H., Oh M., Jeong Y.M., Kim N., Ahn B.O., Park B.S., Park S., Lim K.B., Hwang Y.J., Yu H.J. Construction of a reference genetic map of Raphanus sativus based on genotyping by whole-genome resequencing. Theoretical and Applied Genetics, 2015, 128(2): 259-272 (doi: 10.1007/s00122-014-2426-4).

7. Xu L., Wang L., Gong Y., Dai W., Wang Y., Zhu X., Wen T., Liu L. Genetic linkage map construction and QTL mapping of cadmium accumulation in radish (Raphanus sativus L.). Theoretical and Applied Genetics, 2012, 125(4): 659-670 (doi: 10.1007/s00122-012-1858-y).

8. Hashida T., Nakatsuji R., Budahn H., Schrader O., Peterka H., Fujimura T., Kubo N., Hirai M. Construction of a chromosome-assigned, sequence-tagged linkage map for the radish, Raphanus sativus L. and QTL analysis of morphological traits. Breeding Science, 2013, 63(2): 218-226 (doi: 10.1270/jsbbs.63.218).

9. Yu X., Choi S.R., Dhandapani V., Rameneni J.J., Li X., Pang W., Lee J.Y., Lim Y.P. Quantitative trait loci for morphological traits and their association with functional genes in Raphanus sativus. Frontiers in Plant Science, 2016, 7: 255 (doi: 10.3389/fpls.2016.00255).

10. Kitashiba H., Li F, Hirakawa H., Kawanabe T, Zou Z., Hasegawa Y., Tonosaki K., Shirasawa S., Fukushima A., Yokoi S., Takahata Y., Kakizaki T., Ishida M., Okamoto S., Sakamoto K., Shirasawa K., Tabata S., Nishio T. Draft sequences of the radish (Raphanus sativus L.) genome. DNA Research, 2014, 21(5): 481-490 (doi: 10.1093/dnares/dsu014).

11. Mitsui Y., Shimomura M., Komatsu K., Namiki N., Shibata-Hatta M., Imai M., Katayose Y., Mukai Y., Kanamori H., Kurita K., Kagami T., Wakatsuki A., Ohyanagi H., Ikawa H., Minaka N., Nakagawa K., Shiwa Y., Sasaki T. The radish genome and comprehensive gene expression profile of tuberous root formation and development. Scientific Reports, 2015, 5: 10835 (doi: 10.1038/srep10835).

12. Jeong Y.M., Kim N., Ahn B.O., Oh M., Chung W.H., Chung H., Jeong S., Lim K.B., Hwang Y.J., Kim G.B., Baek S., Choi S.B., Hyung D.J., Lee S.W., Sohn S.H., Kwon S.J., Jin M., Seol Y.J., Chae W.B., Choi K.J., Park B.S., Yu H.J., Mun J.H. Elucidating the triplicated ancestral genome structure of radish based on chromosome-level comparison with the Brassica genomes. Theoretical and Applied Genetics, 2016, 129(7): 1357-1372 (doi: 10.1007/s00122-016-2708-0).

13. Ivy N.A., Biswas M.S., Rasul G., Hossain T., Mian M.A.K. Variations of genotypes of radish at molecular level using isozyme analysis for the identification of self-incompatible lines. Global Journal of Biotechnology \& Biochemistry, 2010, 5(1): 19-26.

14. Cruz S.M., Nery M.C., Pinho E.V, Luiz M. Molecular characterization of radish cultivars. Revista Ciência Agronômica, 2014, 45(4): 815-822 (doi: 10.1590/S1806-66902014000400020).

15. Рудакова А.С., Рудаков С.В., Артемьева А.М., Курина А.Б., Кочерина Н.В., Чесноков Ю.В. Изучение полиморфизма эстеразного состава зрелых семян образцов редиса (Raphanus sativus L.) коллекции ВИР. Овощи России, 2017, 5(38): 3-8 (doi: 10.18619/20729146-2017-5-3-8).

16. Рудакова А.С., Рудаков С.В., Давыдова Н.В., Мирская Г.В., Журавлева Е.В., Чесноков Ю.В. Изоферментный анализ эстераз в зрелых семенах гексаплоидной мягкой пшеницы (Triticum aestivum L.). Сельскохозяйственная биология, 2016, 51(3): 327-334 (doi: 10.15389/agrobiology.2016.3.327rus).

17. Рудакова А.С., Рудаков С.В., Артемьева А.М., Фатеев Д.А., Кочерина Н.В., Чесноков Ю.В. QTL картирование изоферментных форм эстераз зрелых семян у Brassica rapa L. Cельскохозяйственная биология, 2019, 54(3): 469-480 (doi: 10.15389/agrobiology.2019.3.469rus).

18. Nakagahra M., Okuno K., Vaughan D. Rice genetic resources: history, conservation, investigative characterization and use in Japan. In: Oryza: from molecule to plant /T. Sasaki, G. Moore (eds.). Springer, Dordrecht, 1997: 69-77 (doi: 10.1007/978-94-011-5794-0_7).

19. Alexandre F., Morvan, O., Gaffe J., Mareck A., Jauneau A., Dauchel H., Balange A.P., Morvan C. Pectin methylesterase pattern in flax seedlings during their development. Plant Physiology and Biochemistry, 1997, 35(6): 427-436.

20. Timonen S., Sen R. Heterogeneity of fungal and plant enzyme expression in intact Scots pineSuillus bovinus and -Paxillus involutus mycorrhizospheres developed in natural forest humus. New Phytologist, 1998, 138(2): 355-366 (doi: 10.1046/j.1469-8137.1998.00103.x). 
21. Muarlidharan J., John E., Channamma L., Theerthaprasad D. Changes in esterases in response to blast infection in fingermillet seedlings. Phytochemistry, 1996, 43(6): 1151-1155 (doi: 10.1016/S0031-9422(96)00478-5).

22. Pappas A.C., Paplomatas E.J. Pyriculria leaf spot: a new disease of ornamental plants of the family Marantaceae. Plant Desease, 1998, 82(5): 465-469 (doi: 10.1094/PDIS.1998.82.5.465).

23. Parker D.M., Köller W. Cutinase and other lipolytic esterases protect bean leaves from infection by Rhizoctonia solani. Molecular Plant-Microbe Interactions, 1998, 11(6): 514-522 (doi: 10.1094/MPMI.1998.11.6.514).

24. Aung U.T., McDonald M.D. Changes in esterase activity associated with peanut (Arachis hypogea L.) seed deterioration. Seed Science and Technology, 1995, 23(1): 101-111.

25. Miura G.A., Broomfield C.A., Lawson M.A., Worthley E.G. Widespread occurrence of cholinesterase activity in plants. Physiologia Plantarum, 1982, 56(1): 28-32 (doi: 10.1111/j.13993054.1982.tb04895.x).

26. Feng P.C.C., Ruff T.G., Rangwala S.H., Rao S.R. Engineering plant resistance to thiazopyr herbicide via expression of a novel esterase deactivation enzyme. Pesticide Biochemistry and Physiology, 1997, 59(2): 89-103 (doi: 10.1006/pest.1997.2312).

27. Maier R. Blei und seine Auswirkung auf Aktivitzt und multiple Formen der Alpha-NaphtylEasterase in bleichteten und verdunkelten pflanzen. Berichte der Deutschen Botanischen Gesellschaft, 1978, 91(1): 339-350.

28. Cachot J., Romaña L.A., Galgani F. In vivo esterase activity in protoplasts as a bioassay of environmental quality. Aquatic Botany, 1994, 48(3-4): 297-312 (doi: 10.1016/03043770(94)90022-1).

29. Krasnuk M., Witham F.H., Jung G.A. Hydrolytic enzyme differences in cold-tolerant and cold-sensitive alfalfa. Agronomy Journal, 1978, 70(4): 597-605 (doi: 10.2134/agronj1978.00021962007000040019x).

30. Taskakorie A., Clerc M., Thi A.T.P., da Silva J.V. Evidence of esterase activity in cotton leaves: effect of drought on this activity. Comptes rendus del'Academie des Sciences. Serie III. Sciences de la Vie, 2013, 301(6): 343-346.

31. Davis B.J. Disc electrophoresis. II. Method and application to human serum proteins. Annals of the New York Academy of Sciences, 1964, 121(2): 404-427 (doi: 10.1111/j.17496632.1964.tb14213.x).

32. Bradford M.M. A rapid and sensitive method for the quantitation of microgram quantities of protein utilizing the principle of protein dye binding. Analytical Biochemistry, 1976, 72(1-2): 248254 (doi: 10.1016/0003-2697(76)90527-3).

33. Meon S. Protein, esterase and peroxidase patterns of Phytophtora isolates from cocoa in Malaysia. Journal of Islamic Academy of Sciences, 1988, 1(2): 154-158.

34. Nei M. Estimation of average heterozygosity and genetic distance from a small number of individuals. Genetics, 1978, 89(3): 583-590.

35. Lefèvre F., Charrie A. Isozyme diversity within African Manihot germplasm. Euphytica, 1992, 66(1): 73-80 (doi: 10.1007/BF00023510).

36. Вейр Б. Анализ генетических данных. М., 1995.

37. Сазонова Л.В., Власова Э.А. Методические указания по изучению и поддержанию мировой коллекции корнеплодов. Л., 1989.

38. IBPGR. Descriptors for Brassica and Raphanus. International Board for Plant Genetic Resources, Rome, Italy, 1990.

39. Шаяхметов И.Ф., Ахмадиева А.А., Леонова С.А., Никонов В.И. Использование молекулярно-множественных форм белков в изучении полиморфизма сортов пшеницы (Triticum L.). Вестник Башкирского университета, 2012, 17(1): 89-93.

40. Курина А.Б., Корнюхин Д.Л., Артемьева А.М. Генетическое разнообразие и биохимическая ценность корнеплодных овощных растений семейства Капустные (Brassicaceae Burnett). Вестник Новосибирского государственного аграрного университета, 2018, 4(49):81-92 (doi: 10.31677/2072-6724-2018-49-4-81-92).

1 Universitatea de Stat din Moldova,

Republic of Moldova, MD-2009, Chişinău, Mateevich str., 60,

e-mail: rud-as@mail.ru,rudacov@yahoo.com;

\section{2ФГБНУ ФИЦ Всероссийский институт}

генетических ресурсов растений им. Н.И. Вавилова,

190000 Россия, г. Санкт-Петербург, ул. Большая Морская, 42-44, e-mail: akme11@yandex.ru, nastya_n11@mail.ru;

ЗФГБНУ Агрофизический научно-исследовательский

\section{институт,}

195220 Россия, г. Санкт-Петербург, Гражданский просп., 14,

e-mail: alle007@mail.ru,yuv_chesnokov@agrophys.ru $₫$
Поступила в редакцию

21 июня 2020 года 


\title{
POLYMORPHISM OF ESTERASE ISOENZYMES OF RIPE SEEDS OF SAMPLES OF RADISH (Raphanus sativus L.)
}

\author{
A.S. Rudakova', S.V. Rudakov', A.M. Artemyeva ${ }^{2}$, A.B. Kurina ${ }^{2}$, N.V. Kocherina ${ }^{3}$, \\ Yu.V. Chesnokov ${ }^{3}$
}

\author{
${ }^{1}$ Moldova State University, Republic of Moldova, MD-2009, Chişinău, Mateevich str., 60, e-mail rud-as@mail.ru, \\ rudacov@yahoo.com; \\ ${ }^{2}$ Federal Research Center Vavilov All-Russian Institute of Plant Genetic Resources, 42-44, ul. Bol'shaya Morskaya, St. \\ Petersburg, 190000 Russia, e-mail akme11@yandex.ru, nastya_n11@mail.ru; \\ ${ }^{3}$ Agrophysical Research Institute, 14, Grazhdanskii prosp., St. Petersburg, 195220 Russia, e-mail alle007@mail.ru, \\ yuv_chesnokov@agrophys.ru (corresponding author $\square$ )
}

ORCID:

Rudakova A.S. orcid.org/0000-0001-9638-2151

Rudakov S.V. orcid.org/0000-0003-2591-6114

Artemyeva A.M. orcid.org/0000-0002-6551-5203

The authors declare no conflict of interests

Received June 21, 2020

Kurina A.B. orcid.org/0000-0002-3197-4751

Kocherina N.V. orcid.org/0000-0002-8791-1899

Chesnokov Yu.V. orcid.org/0000-0002-1134-0292

doi: 10.15389 /agrobiology.2020.5.956eng

\section{Abstract}

A biochemical approach was used to assess the genetic variability of the seed radish (Raphanus sativus $\mathrm{L}$.) accessions which are distinguished by a wide variety of morphological characters. It is known that the esterase complex in plants has intraspecific specificity; in addition, these enzymes are characterized by tissue specificity. Earlier, the samples of the collections of the genetic resources of the radish were never evaluated for the presence of isozyme forms of esterases in mature seeds of this culture. The establishment of the general variability of isoenzyme systems and the identification of their genetic control make it possible to reveal the subtle mechanisms of the organism's relationship with the environment and homeostasis, which is especially important for long-term storage of samples in genetic seed collections. The development of effective biochemical markers for the rapid assessment of collection, as well as genetically and breeding significant material is also essential. This work allows us to fill the gap that exists in relation to the samples of genetic resources of the radish. From the collection of the Federal Research Center Vavilov All-Russian Institute of Plant Genetic Resources (VIR), 49 radish accessions were selected, belonging to three subspecies, divided according to geographic principle as Chinese, Japanese and European radish. All esterase isozymes of seeds were separated using native vertical electrophoresis in polyacrylamide gel followed by processing for nonspecific esterase. According to their esterase composition, all accessions were subdivided into 7 zymotypes, differing from each other by the presence or absence of certain zones. In total, in the esterase complex of radish seeds, 5 main isozymes with different molecular weights varying from $45.3 \mathrm{kDa}$ to $35.0 \mathrm{kDa}$ were found. All five zones were characterized by a high level of polymorphism among the samples. Based on the composition of isozymes, all genotypes formed 7 zymotypes. Zymotype No. 1, represented by the maximum number of esterases ( 5 zones), comprised of $43 \%$ of the total number of genotypes. Zymotype No. 2 constituted $33 \%$ of all samples. The rarest zymotypes No. 5 and No. 7 (4\%) differed in the minimum amount of esterase enzymes ( 2 zones each). Zymotypes No. 2 and No. 4 were characterized by 4 zones. Representatives of two groups, No. 3 and No. 6 had 3 zones in their esterase complex. The quantitative ratio of all esterase zones varied greatly in the studied samples. The minimum content $(4.78 \%)$ was found for the B5 zone, the maximum amount $(67.44 \%)$ was found for the B1 zone. The prevalence of each zone among all studied samples ranged from 13 to $23 \%$. Zones $\mathrm{B} 3(\mathrm{Mr}=39.7 \mathrm{kDa})$ and $\mathrm{B} 4(\mathrm{Mr}=37.1 \mathrm{kDa})$ were the most common among all esterase isozymes; these zones were observed in $23 \%$ of genotypes. For $22 \%$ of representatives, the B2 zone was characteristic $(\mathrm{Mr}=42.9 \mathrm{kD})$. Zones $\mathrm{B} 1(\mathrm{Mr}=45.3 \mathrm{kD})$ and $\mathrm{B} 5(\mathrm{Mr}=35 \mathrm{kD})$ were less common, $19 \%$ and $13 \%$, respectively. The average heterozygosity of isozygous forms of esterases of the studied radish samples was $H_{\text {total }}=0.212$, with variance for the same samples $\operatorname{Var}\left(H_{\text {total }}\right)=0.0007$. Cluster analysis of esterase enzymes divided the studied set of radish samples into European and Asian subspecies and varieties, and together with phenotypic traits, it allowed constructing a dendrogram corresponding to the botanical, agrobiological and geographical location of the samples. It should be noted that the accessions of the European subspecies radish are located in two clusters, and the accessions of Russian origin form a separate group in the first cluster, and the samples of European origin are grouped in the third cluster which also includes Japanese radishes of European origin. Perhaps this division is associated with the peculiarities of the selection process in creating these samples. Based on the data obtained, esterase enzymes are recommended as biochemical markers in genetic selection experiments.

Keywords: Raphanus sativus L., morphological characters, phenological characters, seeds, esterases, isoforms, zymotypes, polymorphism, biochemical markers, clustering. 